The Geneva Papers on Risk and Insurance, 21 (No. 81, October 1996), 478-501

\title{
Managing an Ageing Workforce in Britain and France
}

\author{
by Anne-Marie Guillemard*, Philip Taylor** and Alan Walker***
}

\section{Introduction}

The purpose of this paper is to present the results of a comparative study of the practices, opinions and attitudes of employers with regard to the management of their older employees and, more generally, to the ageing of the workforce. We also attempt a preliminary evaluation of the practices and attitudes of employers. The context of this research is of the greatest contemporary socio-political relevance for two main reasons.

First, the slowing-down of economic activity and the rise in unemployment, all over Europe, have encouraged the multiplication of intermediate social security and employment schemes bridging economically active life and retirement. These arrangements, whether they are relatively unstable combinations bringing into play different sub-systems of social protection or arrangements geared to specific employment situations such as public or private early retirement schemes, have encouraged and helped to institutionalise a farreaching trend towards early exit from working life in all EU countries. This trend shows no sign of slackening in all EU countries and beyond (Walker, Guillemard and Alber, 1993; Kohli, Rein, Guillemard and Van Gunsteren, 1991).

Secondly, more recently a growing awareness of the imminent acceleration of demographic ageing in developed societies has led governments to concern themselves with the long-term financial balance of retirement pension schemes and, with this in mind, to attempt to influence the above-mentioned trend towards early exit from active economic life. This is all the more important in that demographic ageing will also bring about an internal ageing of the workforce within organisations. Thus in Britain and France the average age of the active population will be more than 40 by the year 2005 . This situation gives rise to a serious problem in the context of age discrimination in the labour market where workers aged over 40 are considered to be at the end of their careers and, therefore, without a future in employment (McEwan, 1990; Drury, 1993).

\footnotetext{
* University of Paris I, Panthéon Sorbonne.

** Policy Studies Institute, London.

*** Sheffield University, Sheffield.
} 
The research we are undertaking is the sequel to a long series of studies of early exit conducted in the 1970s and 1980s, including a comparative study of the transformations in the processes of exit from active employment carried out in 1989 and 1990 (Kohli, Rein, Guillemard and Van Gunsteren, 1991). That study was concerned with the movement towards early exit in the industrial societies and compared the early exit schemes set up in seven countries: France, Germany, Great Britain, the Netherlands, the USA, Sweden, and Hungary.

The present research both builds on and departs from previous work on early exit. In particular it aims to deepen our knowledge of one of the key actors in the employment of older workers, namely employers themselves, the extent of whose influence was made apparent by many previous studies. More precisely, with regard to age or age management, the role of employers has so far been studied very little by comparison with research on public policy and practice in this field. Our current research is also international, covering Britain, Canada, France, Germany, Japan, the Netherlands, Sweden and the USA. However this paper focuses on Britain and France because these were the two countries in which the comparative research was commenced, where the methodological approach is closest and where the studies of employers' attitudes and policies have progressed furthest.

\section{Older people in the labour market: Britain and France}

Britain and France, in common with all other industrialised societies except Japan and Sweden, have experienced a decline in the employment of older men since the 1950 s (Kohli, Rein, Guillemard and Van Gunsteren, 1991). This accelerated in the late 1970s and 1980s and, as Table 1 and Graph 1 show in Britain, resulted in just over three quarters of men aged 55-59, just over half of men aged 60-64 and less than one-tenth of men aged 65 and over being economically active in 1991 for Great Britain. The proportions are even

Table 1: The comparative evolution of the male employment rate by age groups from 1971 to 1991 in France and Great Britain

$\begin{array}{llllllll}1971 & 1975 & 1980 & 1985 & 1987 & 1989 & 1991 & \text { Variations Variations }\end{array}$

in points in percent

Age 55-59

\begin{tabular}{|c|c|c|c|c|c|c|c|c|c|}
\hline France & 80.8 & 81.3 & 77.4 & 62.6 & 61.1 & 62.5 & 64.2 & -16.60 & -21.0 \\
\hline GB & 89.7 & 89.7 & 84.7 & 68.2 & 65.3 & 70.4 & 71.6 & -18.10 & -20.0 \\
\hline \multicolumn{10}{|c|}{ Age 60-64 } \\
\hline France & 65.7 & 55.1 & 44.9 & 29.4 & 24.8 & 23.2 & 19.1 & -46.60 & -71.0 \\
\hline GB & 75.5 & 74.6 & 60.6 & 50.5 & 50.6 & 52.3 & 51.0 & -24.50 & -32.0 \\
\hline \multicolumn{10}{|c|}{ Age 65 and over } \\
\hline France & 18.2 & 13.6 & 7.5 & 5.2 & 4.7 & 4.3 & 3.5 & -14.70 & -81.0 \\
\hline GB & 19.2 & 15.6 & 10.2 & 8.3 & 7.7 & 9.0 & 8.4 & -10.85 & -56.0 \\
\hline \multicolumn{10}{|c|}{ Total ages 55-64 } \\
\hline France & 73.0 & 67.1 & 65.3 & 46.7 & 43.9 & 43.6 & 42.0 & -31.00 & -42.5 \\
\hline GB & 82.9 & 82.0 & 73.9 & 59.4 & 58.1 & 61.6 & 61.5 & -21.40 & -25.8 \\
\hline
\end{tabular}

Sources: OCDE, Working population statistics, and our own calculations. (Guillemard, 1993, p. 64) 
Graph 1: Evolution of the male employment rates for ages 56-64 in nine countries

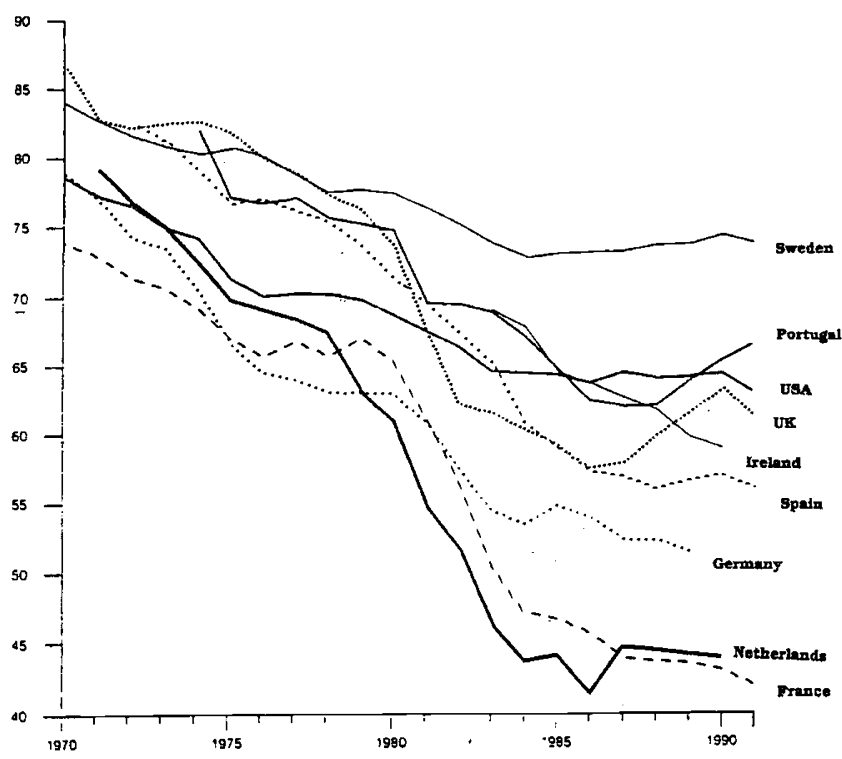

less for France, since that country is, along with the Netherlands, the one which has made the most use of early exit for ageing workers compared with other European countries. The participation of women in the labour force has tended to increase slightly since the 1970 s, though the cross-sectional data are bedevilled by the cohort effect of increased labour force participation of women in the post-war period. When this cohort effect is disentangled, women display the same early exit trend as men (Kohli et al, 1991).

The main factors explaining the growth of early exit among British men are demand related, particularly the recessions of the mid-1970s and early 1980s (Walker, 1985; Trinder, 1990). In fact it has been argued that 'early retirement' or withdrawal from the labour market brought about through an increase in unemployment is better understood as a form of unemployment rather than as a form of retirement (Casey and Laczko, 1989; Guillemard, 1993). Looking over the post-war history of older people in the British labour market reveals a pattern that is akin to their use as a reserve army of labour: in the economic boom of the late 1950 s older people were encouraged to remain in employment while in the recessions of the mid 1970 s and early 1980 s older people were actively encouraged to take early retirement (Phillipson, 1983; Walker, 1985). In both periods public policies played important roles in the retention or the displacement of older workers.

In the case of France the main engine driving early exit has also been the collapse in the demand for labour. This context of economic crisis allowed the social partners - the state, employers and trade unions - to reach a new consensus on the question of early retirement for ageing workers. The participants simplified their perception of what is at stake by concentrating on the issue of the regulation of employment, thus unifying their 
approach in a corporatist compromise. The participants thus agreed, for different motives, to encourage early exit from the labour market for ageing workers (Guillemard, 1986). The result was a spectacular reduction of activity after age 55 .

\section{The State and older workers}

In the period of acute labour shortages in Britain immediately following the Second World War people of retirement age were urged officially not to retire and 'sink into premature old age', but to work a little longer and, therefore, have a 'happier and healthier old age' (Phillipson, 1983, p. 33). A National Advisory Committee on the Employment of Older Men and Women was established in 1951 to draw attention to the labour shortages and to encourage older workers to defer retirement. (At the same time medical and social science research began to indicate that retirement could have detrimental effects on health.)

In summarising the relationship between the state and older workers in Britain it is essential to mention the role of the retirement condition, which governs the receipt of the national insurance (NI) pension. This was a major contributory factor in the establishment of the pension ages (men 65, women 60) as the customary retirement ages (Walker, 1980). Similarly the introduction of age and service related redundancy payments in 1965 legitimated the use of age as a criterion for redundancy and challenged the 'first in, last out' principle (Mukherjee, 1973).

The advent of mass unemployment, following the Yom Kippur war and world oil crisis of the early 1970 s, led to a dramatic reversal in the state's attitude towards older workers. The early exit of this group from the labour force came quickly to be seen as a 'solution' to unemployment. In 1975 the contribution conditions for the receipt of an NI retirement pension were eased. In 1977 the Job Release Scheme was introduced, as a temporary measure, to create vacancies for unemployed people by encouraging older workers to leave their jobs. Those receiving job release allowances were not allowed to take up paid employment and employers using the scheme had to undertake to recruit an unemployed worker for each older worker leaving employment under it. The scheme was extended in the early 1980 s and, at its peak in $1984 / 85$, 90,000 older people were in receipt of allowances (over half of them were previously employed in the manufacturing sector). In 1981 an additional incentive for older unemployed men to leave the labour market was introduced: those aged 60-64 were awarded a higher rate of social assistance if they withdrew from the unemployment register.

The brief period of economic expansion in Britain in the late 1980s and fears about the demographic timebomb led to a change in state policy towards older workers which has culminated in a recent campaign by the Department of Employment to discourage employers from discriminating on grounds of age. In 1989 the Job Release Scheme was replaced by the 50 plus Job Start Allowance, whereby an older person received an extra amount on top of the wage or salary paid by the employer if they remained in or re-entered the labour force. However the scheme was abandoned in February 1991 because of low take-up. Also in 1989 the government abolished the 'earnings rule' which restricted the amount of money older people beyond pension age could earn before their NI pension was reduced. In 1991 the regulations governing the receipt of state benefits by the over 50s 
were altered so that this group are required to register themselves as available for work every two weeks instead of every three months.

In 1993, reflecting its favoured supply-side approach to the economy, the British government established a Ministerial Advisory Group on Older Workers and, in response to the research reported here - especially the finding that some two-fifths of employers were using age as a criterion in recruitment (Taylor and Walker, 1993), - a special campaign was launched. The Getting $O n$ plan promoted by Employment Minister Ann Widdecomb urged employers to abolish age bars from job advertisements; encourage applications from older workers; base selection on tests of ability to do a job rather than educational qualifications; offer flexible working arrangements; and continue to train staff regardless of their age. The Getting On booklet was mailed to 165,000 employers. Unfortunately the same research that helped to spawn the government's educational campaign also showed that similar approaches in the past have met with little success, even among some of Great Britain's largest and most prestigious employers. Also, given the post-Fordist deconstruction of management arrangements, with greater responsibility for human resource issues being decentralised to local and line managers, it is even less likely that such promotional campaigns will achieve the internal diffusion and penetration they require to be successful. The government did take a more positive step, also in response to the research reported here, by raising the age of eligibility for the Training for Work Scheme from 59 to 63 .

As in Britain, since the second world war the public authorities in France have played an important part with regard to the employment of older workers. However, in France, up until the beginning of the 1970s, encouragement to continue the employment of older workers was given essentially by the mechanisms of retirement pensions. Indeed, until 1983 there was strong encouragement given to the prolonging of economic activity after age 65 , and a heavy penalty attached to taking a retirement pension before that age, which was the lower limit fixed for accession to a full pension under the social security general scheme. After age 65, workers were encouraged to remain in employment to the extent that there was a bonus system whereby four points were added to the pension rate for every year deferred after the age of 65 . Again, at the start of the 1970s, the public authorities still adhered to the principle that people should be maintained in economic activity at least until age 65. Thus, the Boulin Act of 1971, was the main piece of reforming legislation to affect public pension schemes since 1945, which kept the retirement age at 65 despite trade union pressure to reduce it.

There are few traces of an active employment policy towards ageing workers. On the other hand, from the middle of the seventies onwards there has been an ever more active commitment on the part of the French public authorities in their encouragement of early exit from working life. Furthermore, this policy led the socialist government to lower the age of entitlement to a full retirement pension from 65 to 60 , France being the only country in Europe to act in this way (Guillemard, 1991). The policy of early exit from the labour market was implemented with greater determination than in Britain, where arrangements such as the Job Release Scheme were used much more sparingly than were the French early retirement schemes, and these arrangements have allowed massive exits from the age of 55 onwards for the workforce as a whole (Guillemard, 1991). 
However from the end of the 1980s the public authorities in most EU states have reorientated their position. After a long period in which the public debate was concerned with early exit for older workers as a solution to the problem of unemployment along with a measure of agreement, for different reasons, between the unions, the employers, and the state, we can now observe the emergence of a more fragmented debate as new policy imperatives appear. Wherever the movement towards early exit has acquired significant momentum, attempts are being made to apply the brakes and to substitute for an ever earlier and more abrupt exit a more flexible transition, giving rise to the launching of new formulae for partial retirement or progressive early retirement, or a more flexible retirement process. Two main factors have brought about this recasting of the retirement debate in Europe. The first of these is constituted by the financial costs inflicted by early exit schemes upon systems of social protection already in crisis. The second is the need for the reform of retirement pension systems whose financial balance is placed in jeopardy by the acceleration of demographic ageing in Europe due to take place by the start of the third millennium.

The major challenge to governments from the end of the 1980 s onwards has been to contain, in the medium and long term, the risks of public retirement pension schemes becoming bankrupt. Priority is no longer given, as it was previously, to the social management of the rise in unemployment or the provision of employment for young people. This new central challenge has given rise to three forms of public intervention.

In the first place, public authorities are attempting everywhere to control and limit the mounting waves of early exit. The objective is, on the one hand, in the short term, to refuse to make any further financial commitment in this area, and on the other hand, in the medium term, to attempt to stem the strong tendency towards early retirement from the labour market by setting up partial retirement schemes which allow the partial maintenance of older workers in the labour market. These arrangements constitute one way of prolonging working life despite a general context in which the problem of unemployment remains acute. Seen in this light, the switch to part-time working for older workers appears therefore as a compromise solution.

The second major direction of intervention by governments concerns the reform of public retirement pensions. Such reform has already taken place in Germany, Italy, France and Britain and still remains high on the political agenda in Britain. The main emphasis of this reform seems to be common to all the European Union countries: its aim is to encourage a prolongation of the working life. The raising of the age of access to full retirement pensions or the lengthening of the period of insurance contributions are the two main elements of this new policy. Reform must also encourage greater flexibility in the transition between activity and retirement. There is no doubt that the most significant expression of this new concept of flexibility is the British slogan 'a decade for retirement' (Schuller and Walker, 1990). According to this notion, it ought to be possible to enter retirement any time between ages 60 and 70 . Individual choices of when to go should be more open and allow greater individual freedom of decision. This new emphasis is perceptible everywhere even if it still remains mostly at the intentional stage: so far only Belgium has introduced flexible retirement. Regarding the reforms actually under way, we may observe that a certain number of restrictions on the pursuance of working activity after retirement have been lifted. For example, there is the abolition of regulations limiting the combination of employment with the right to a retirement pension in Britain, and new possibilities in 
Germany for improving the level of retirement pensions by the prolongation of activity beyond full retirement age and, in France, the gradual raising of the length of insurance cover from 37.5 years to 40 years will in the long term lead to the lengthening of the economically active span and the reduction of the importance of age and especially its brutally abrupt effect upon the taking of retirement.

The third aspect of public policy has to do with employers being encouraged to keep on their older staff and even to recruit older people. Indeed, there is a danger that the reform of retirement age may be irrelevant in terms of bringing into balance the numbers of economically active and inactive older people, if such reform is not accompanied by measures which ensure that, before their definitive break with the world of work, older people benefit from greater protection and better integration into their working environment. It is however the case that there have been no significant new developments in the last few years in public employment policies for the protection of workers at the end of their career. It seems that only a few countries have introduced measures to this end and even then only at a very low level.

\section{Schemes to protect workers towards the end of their careers}

In 1988 the British government replaced the Job Release Scheme, which was the means of substituting younger for older age groups in the labour market, by the 50 plus Job Start Allowance Scheme, which aimed to allow older unemployed people to return to work via part-time activities. France also attempted to encourage a return to work by Return to Employment Contracts (Contract de Retour à l'Emploi, CRE) for the over-fifties. Despite heavy financial incentives to employers (in France the Return to Employment Contract for the over-fifties exempts employers from paying social security contributions for such workers up to the time of their retirement), companies were in general reluctant to take advantage of these schemes. This reluctance led to the abandonment, in February 1991, of the British Job Start Allowance Scheme.

In France, the CRE (Return to Employment Contracts) arrangements have been continued. Moreover, a new measure, namely the Delalande Amendment, has from 1987 onwards penalised those employers who make workers over age 55 redundant for economic reasons (age 50 as of June 1992). This penalisation, which is intended to prevent long term unemployment (defined as exclusion from employment of this age group) among ageing workers, takes the form of a supplementary employer's contribution to unemployment insurance, in the form of a sum equal to 3-6 months' gross earnings.

Here too we may note that intervention by the public authorities, even though subject to global restraint, has been somewhat less reserved in France than in Great Britain. Indeed, from 1991 onwards in France, in addition to public exhortations, there have been certain measures which attempt to encourage employers to retain their older workers in employment. These comprise, on the one hand, all the measures to encourage alternatives to redundancy in terms of reconversion or reclassification incorporated into social plans (the creation of reclassification groups, retraining and adaptation agreements, of the National Employment Fund). The signing by employers and public authorities of the ASFNE convention on total early retirement within a business is itself conditioned by the commitment by the firm involved to limit or even exclude any redundancy affecting wor- 
kers over age 50 . The clear objective of a social plan negotiated between public authorities and an employer is the permanent modification of the latter's behaviour with regard to the maintenance in employment of ageing workers. Indeed, by signing a total early retirement convention, public authorities seek to obtain systematically certain reciprocal actions (Kershen and Nenot, 1989). In return for the financial help afforded by the state, the business concerned must make a qualitative effort to limit the use of total early retirement, which should be replaced by progressive early retirement and by attempts to maintain older workers in employment.

On the other hand recent French active labour market interventions include some measures outside the social plans, with a view for example to the systematic retraining and requalification of staff (the commitment to training development), or the continuance and public assistance in part-time employment of older workers (progressive early retirement). This last measure has been renovated and made more attractive, both for employers and for workers, at a time when public authorities have been exercising tighter control over total early retirement pensions from the National Employment Fund, pushing entitlement age up from age 55 to age 57 for full early withdrawal.

\section{Employers' responses to the ageing of their workforces}

Having outlined the policy context in Britain and France and, in particular, highlighted the transition in public policy from the encouragement of early exit to the extension of working life, our attention now turns to research on the responses of employers to workforce ageing.

\section{Recent British research on employers' attitudes and policies}

During the late 1970s and early 1980s, when Britain experienced the simultaneous contraction of full-time employment and historic high points in the number of young people entering the labour market and, as a consequence, when early exit was at its peak, social scientific research tended to concentrate on this issue (see for example, Casey and Bruche, 1983; Casey and Laczko, 1989; Laczko, Dale, Arber and Gilbert, 1988; Laczko and Walker, 1985; Walker, 1982, 1985). With the rapid expansion of the British economy in the late 1980s, coupled with a predicted demographic 'timebomb' (NEDO, 1989) of falling numbers of young labour market entrants, the attention of both policy-makers and researchers began to focus on the attitudes of employers towards the recruitment and retention of older workers. It was in this short-lived period of reversal in the post-war employment fortunes of older workers that the British research reported here, and partly replicated in France, was born.

There have been few previous studies of British employers' practices and attitudes with regard to older people. Thompson (1991) carried out a large scale postal survey of private sector employers in 1990 and asked a range of questions regarding the extent to which employers were changing their recruitment and retention policies in order to increase the numbers of older workers in employment. The study showed that at that time only a minority of employers were doing so and only a few were considering such action in the future despite the evidence from the study that employers were experiencing skill and labour shortages. Employers that were orientating towards older people did so because this group was considered to be more reliable and because it was believed they were able 
to carry out the jobs a particular employer was offering. These employers were most likely to be in the construction, transport and minerals sectors. Employers perceived that there were important supply side factors limiting the extent to which they could orientate towards older workers, including a shortage of older applicants and a lack of skills and qualifications among older workers. Another key finding of this research was that just under a fifth of employers reported age restrictions on jobs (Thompson, 1991).

Results from recent studies of older workers' experiences in the labour market (Walker and Taylor, 1993) indicate that older people in the early 1990s seeking work continue to face considerable discrimination from employers. Age restrictions in job advertisements are often cited by older people as barriers to employment. Support for such views comes from research on the use of age bars in recruitment adverts. For example a study of advertisements placed in Job Centres showed that 11 per cent of vacancies were not open to people aged 60 years or over (Jones and Longstone, 1990). A survey undertaken by the Institute of Personnel Management (IPM), in 1987, of adverts in its own publication and in the Sunday Times found that 32 per cent were age-limited while in the latter 41 per cent expressed an age preference (Naylor, 1987). Despite the publication of a professional code, 2 years later Tillsley (1990) found that 24 per cent of posts in the IPM's journal specified upper age limits, the majority of which ranged from a minimum age of 25 to a maximum age of 40 . As far as the national press was concerned, the figure was 11 per cent and for the local press 9.5 per cent. Age bars to recruitment were most likely to be found in sales and marketing posts, access being restricted to those people in their early 20 s to late $30 \mathrm{~s}$. Without actually specifying age bars in advertisements, recruitment practices may also discriminate against older people. For example, the specification of education, qualification and experience standards in advertisements can restrict applicants to a desired age range while other statements in job advertisements can imply that a younger person would fit better into the work team (McGoldrick and Arrowsmith, 1992).

A small scale survey of 20 employers carried out in order to examine attitudes and practices towards older workers showed that, in response to demographic changes, employers were taking more active steps to recruit older people (Metcalf and Thompson, 1990). However, employers felt that older people were suitable for employment only in low skill, low responsibility and repetitive jobs while physically demanding, time pressured or IT based jobs were deemed unsuitable. Employers also considered older workers less trainable. Methods aimed at recruiting more older workers included creating more parttime jobs and giving all part-timers permanent status and pension rights in order to make these jobs more attractive. Employers were enthusiastic about such options as a 'flexible decade of retirement' and the equalisation of the male and female state pension ages.

A subsequent study of the employment of older workers in local government conducted by Itzin and Phillipson (1993) found that local authorities were only just beginning to introduce positive older worker policies. While authorities were beginning to make efforts to remove age bars in recruitment advertisements, and one third included age in their equal opportunities policies, early retirement was being actively used by the majority as an alternative to compulsory redundancy in the reduction of staffing numbers. Policies such as phased retirement and job-redesign to better accommodate older employees had seldom been implemented. In addition, line manager attitudes towards and beliefs about older workers were identified by senior management respondents as being significant obs- 
tacles to the recruitment, training and promotion of older workers. Finally, Warr and Pennington (1993) have conducted a large scale postal survey of personnel managers and found ambivalence in their attitudes concerning older staff. Although this age group were seen as being more 'effective' than average in terms of experience, loyalty, reliability, conscientiousness and team working, they are also viewed as being less adaptable.

\section{Comparative analysis of the attitudes and policies of British and French employers}

The results presented in this study are the preliminary elements of a wider international study ranging over eight countries (France, Great Britain, the Netherlands, Germany, Sweden, the USA, Canada, and Japan), the central theme of which is 'ageing at work: employers' strategies and public policies'. The objective of this international research is twofold. In the first place to compare the different objectives and approaches of employers with regard to ageing at work in the different countries, and to analyse their principal economic and social determinants. The mechanisms governing judgements about older people in the workplace will be shown and compared: in particular, the criteria used by employers from one sector to another to determine the capabilities of workers according to their age and to justify judgements about older workers in certain types of employment. The second aspect of the comparative international research will concentrate on the analysis of the dynamics of the relationships between the state and employers with respect to the employment or retirement of older workers.

\section{Methodology and analytical approach}

The French and British cases have adopted an identical two-stage methodology. The first quantitative stage used a postal questionnaire addressed to senior management in a national sample of organisations concerning their attitudes, opinions, and political options with regard to the ageing of the workforce and to older workers. The second qualitative phase is comprised of in-depth follow-up studies of organisations selected from the original sample. This preliminary chapter will take into account only the very first comparative results arising from the quantitative phase based on the analysis of the postal questionnaires sent to employers. A certain number of questions were common to the two postal questionnaires, especially those about opinions, which may be used to draw a comparison (see the appendix for the constitution of the samples for the two postal surveys).

The two studies started from the same theoretical perspective, which postulates the heterogeneity of 'worlds of production' (Salais and Stozper, 1993), giving rise to diversified forms of behaviours, of judgements about age, and of political orientations with regard to the ageing of the workforce. In referring to 'worlds of production' we adopt the terminology of Strauss (1978) and the symbolic interactionists, who use the concept of 'social worlds'. Thus the comparison reveals one notable first result. The opinions of employers concerning ageing workers have no direct or strong relationship with the ageing or otherwise of their organisation's age structure. Moreover, employers have only an imprecise idea of the level of ageing of their workforces. In fact, the opinions and practices of employers towards their workers seem to obey the specific rules governing the production worlds to which they belong. According to the type of product or the service sold by the business, different technological changes will occur in the production process, resulting in the obsolescence of skills and aptitudes among older workers, in stereotypes, or judgements about age, and in practices concerning ageing workers and ageing in general. 


\section{Managing an ageing workforce}

What measures did these establishments envisage taking in the future in response to the ageing of their workforces? It appears that employers are led to opt more often than not for the rejection, in various forms, of ageing workers (early retirement and obligatory retirement retain a central role), rather than for their maintenance within the organisation via internal reclassification or the reorganisation of working practices.

Respondents in the French survey were asked to give their opinion as to the use of the following methods for the management of the ageing of the workforce: dismissal, encouragement to take early retirement, retirement, internal regrading in the company or regrading outside the company and possible internal reorganization of work. This question did not imply any particular relation to envisaged trends in the workforce, but was placed in the section of the survey dealing with trends in the proportion of ageing employees and its possible consequences for the establishment, and could thus be interpreted as inviting a response to an increase in the numbers of older employees.

Forced retirement was mentioned the most often by a little over half of the establishments. Immediately afterwards came encouragement to take early retirement, which was mentioned by more than one in three establishments. Internal regrading within the company was also envisaged by a sizeable proportion of them ( 25 per cent) as well as internal reorganisation of work, whereas regrading outside the company was seen as likely by less than one in ten establishments. Finally, 13 per cent said that dismissal would be their main response (Table 2).

\section{Table 2: A possible increase in older workers aged 50 and over in your company (France)}

is not a problem (1)

is a problem, but there is no particular solution to it (2)

is a problem, but it can be solved by internal re-organisation of the company (3)

is a problem, and the number of such workers must be reduced (4)

no response

Total
37.4 Case (1)

21.4 Case (2)

21.8 Case (3)

13.5 Case (4)

6.9

$100.0 \%$

In general, if a company observes an increase in its workers

of age $50+$, which of the following measures should be envisaged?

Case (1) Case (2) Case (3) Case (4) employers 1

\section{Redundancies}

Entirely envisageable or practicable

Envisageable but not appropriate

Ruled out, wholly inappropriate

Don't know

Total

\section{Incentives for early exit}

Entirely envisageable or practicable

Envisageable but not appropriate

Ruled out, wholly inappropriate

Don't know

Total

$\begin{array}{ccccc}11.1 & 9.9 & 9.5 & 30.3 & 12.7 \\ 21.4 & 24.1 & 34.0 & 24.3 & 24.5 \\ 45.7 & 45.0 & 42.7 & 19.9 & 29.9 \\ 21.8 & 21.0 & 12.8 & 25.6 & 22.9 \\ 100.0 \% & 100.0 \% & 100.0 \% & 100.0 \% & 100.0 \%\end{array}$

$\begin{array}{ccccc}32.4 & 36.7 & 42.4 & 60.2 & 37.8 \\ 34.4 & 30.4 & 40.3 & 20.4 & 31.6 \\ 14.6 & 13.9 & 4.0 & 11.5 & 11.5 \\ 18.6 & 19.0 & 13.3 & 8.0 & 19.1 \\ 100.0 \% & 100.0 \% & 100.0 \% & 100.0 \% & 100.0 \%\end{array}$

1 All establishments with 500 or more employees. 


\section{Enforced retirement}

Entirely envisageable or practicable

Envisageable but not appropriate

Ruled out, wholly inappropriate

Don't know

Total

Reclassification within the company

Entirely envisageable or practicable

Envisageable but not appropriate

Ruled out, wholly inappropriate

Don't know

Total

Internal re-organisation of working practices

Entirely envisageable or practicable

Envisageable but not appropriate

Ruled out, wholly inappropriate

Don't know

Total

\section{External reclassification}

Entirely envisageable or practicable

Envisageable but not appropriate

Ruled out, wholly inappropriate

Don't know

Total
Case (1) Case (2) Case (3) Case (4) employers

$\begin{array}{ccccc}46.4 & 51.5 & 40.5 & 67.2 & 47.4 \\ 20.3 & 21.8 & 33.6 & 12.7 & 22.0 \\ 15.0 & 12.7 & 15.3 & 6.7 & 13.0 \\ 18.3 & 14.0 & 10.6 & 13.4 & 17.6 \\ 100.0 \% & 100.0 \% & 100.0 \% & 100.0 \% & 100.0 \%\end{array}$

$\begin{array}{ccccc}25.1 & 21.8 & 32.9 & 17.5 & 24.5 \\ 35.9 & 40.5 & 45.6 & 46.6 & 39.1 \\ 18.1 & 15.8 & 11.8 & 13.9 & 14.8 \\ 20.9 & 22.0 & 9.8 & 22.0 & 17.6 \\ 100.0 \% & 100.0 \% & 100.0 \% & 100.0 \% & 100.0 \%\end{array}$

$\begin{array}{ccccc}26.0 & 14.3 & 36.6 & 7.9 & 22.5 \\ 34.3 & 45.2 & 46.2 & 42.6 & 39.5 \\ 23.2 & 17.5 & 9.5 & 27.2 & 18.4 \\ 16.6 & 22.9 & 7.8 & 22.4 & 15.9 \\ 100.0 \% & 100.0 \% & 100.0 \% & 100.0 \% & 100.0 \%\end{array}$

$\begin{array}{ccccc}9.1 & 5.6 & 3.2 & 11.2 & 7.3 \\ 21.7 & 24.5 & 34.0 & 24.4 & 24.6 \\ 48.0 & 46.5 & 51.1 & 40.4 & 45.4 \\ 21.2 & 23.0 & 11.8 & 24.0 & 22.7 \\ 100.0 \% & 100.0 \% & 100.0 \% & 100.0 \% & 100.0 \%\end{array}$

Source: French survey of employers, Ministry of Labour, DARES, France.

These same methods of workforce management were proposed to employers in the hypothetical case of an increase of employees aged 50 and over. It was already known whether or not these same establishments saw this possible increase (again in terms of level) in their ageing workforce as a problem. Despite a sometimes low rate of response to this question, some major differences were apparent in employers' intentions as to future action with regard to the ageing of their workforce.

Establishments wishing to reduce the number of older employees (because it was regarded as a problem) believed that it was definitely feasible to resort to retirement, early retirement and dismissal in high proportions, much higher than those proposed by other establishments - 37 per cent, 60 per cent and 67 per cent respectively. In other cases, the proportion of those declaring that dismissal was perfectly feasible never exceeded 11 per cent and the proportion for early retirement was a maximum of 42 per cent.

In the British survey, employers were asked whether or not the average age of their workforce was increasing: 45 per cent said yes and 47 per cent said no. Of those saying yes, 29 per cent thought that this was of no importance for their organisation, 24 per cent thought it was of little importance, 40 per cent thought it was of some importance and only 8 per cent said it was of great importance.

${ }^{1}$ All establishments with 500 or more employees. 


\section{Employers' ambivalence towards older workers and the consequences of the ageing of the workforce}

What would be the consequences of a possible increase in the proportion of employees aged 50 years or over in establishments? In both countries there were a mixture of positive and negative responses to this scenario.

The British survey asked employers a number of questions about the problems they might encounter if the average age of their workforce is increasing. As Table 3 shows, most organisations did not believe that an ageing workforce would force employers to improve working conditions, re-organise the production programme, lead to falling productivity or a poor image with customers. However over half the employers felt that an ageing workforce would result in little enthusiasm for new technology and increased resistance to change. Almost a third of employers also felt that an ageing workforce would result in increased labour costs. There were few differences between industrial sectors in their perceptions of the problems associated with ageing workforces. Service sector companies were more likely to regard as problematic having to improve working conditions. But production and construction industries were more likely to state that falling productivity and little enthusiasm for new technology would be problems. The two groups did not differ statistically on the other items.

\section{Table 3: Potential Problems of an Ageing Workforce ${ }^{2}$ (Britain)}

$\begin{array}{lccccc} & \begin{array}{c}\text { Yes } \\ \text { definitely } \\ \%\end{array} & \begin{array}{c}\text { Yes-quite } \\ \text { likely }\end{array} & \begin{array}{c}\text { Not } \\ \text { sure } \\ \%\end{array} & \begin{array}{c}\text { No-not } \\ \text { very likely } \\ \%\end{array} & \begin{array}{c}\text { No-definitely } \\ \text { not } \\ \%\end{array} \\ \text { Having to improve working conditions } & 2.0 & 11.2 & 9.2 & 55.6 & 18.4 \\ \text { Re-organising the production programme } & 1.0 & 11.5 & 16.8 & 42.4 & 17.4 \\ \text { Falling productivity } & 0.7 & 10.9 & 17.8 & 47.4 & 17.1 \\ \text { Little enthusiasm for new technology } & 4.6 & 46.7 & 15.1 & 26.0 & 4.3 \\ \text { Increase in resistance to change } & 8.6 & 47.7 & 15.1 & 21.7 & 3.9 \\ \text { A poor image with customers } & 2.0 & 7.2 & 13.2 & 46.1 & 28.0 \\ \text { Increased labour costs } & 2.3 & 25.7 & 16.8 & 37.5 & 12.9\end{array}$

Source: British survey (A. Walker and P. Taylor)

In the French survey the answers given to the possible consequences of an increase in the proportion of older employees were very positive ${ }^{3}$ with respect to the presence of a corporate memory (Tables 4-7). Nearly two-thirds of establishments believed that such an increase would certainly result in the existence of a corporate memory. However, it is difficult to explain the real content of this declaration and its exact weight in the employment and management of older employees.

2 Table excludes missing values.

3 'very positive' indicates that there is a large majority of establishments that believe that a possible increase in the proportion of ageing employees would result in the presence of a corporate memory. 
Table 4: Consequences of a possible increase in older workers aged 50 and over: a study of option selection in the answers (France)

\begin{tabular}{|c|c|c|c|c|c|c|c|}
\hline & \multicolumn{3}{|c|}{ Extreme Options } & \multicolumn{3}{|c|}{ Central Options } & \multirow{2}{*}{\begin{tabular}{|c|} 
Points \\
difference
\end{tabular}} \\
\hline & $\begin{array}{l}\text { yes (1) } \\
\text { certainly }\end{array}$ & $\begin{array}{c}\text { no (2) } \\
\text { certainly } \\
\text { not }\end{array}$ & \begin{tabular}{|c} 
points \\
difference \\
(1) - (2)
\end{tabular} & $\begin{array}{l}\text { Yes (3) } \\
\text { perhaps }\end{array}$ & $\begin{array}{c}\text { no (4) I } \\
\text { don't think } \\
\text { so }\end{array}$ & \begin{tabular}{|c} 
points \\
difference \\
(3) - (4)
\end{tabular} & \\
\hline Presence of a corporate memory & 62 & 2 & 60 & 22 & 9 & 13 & 73 \\
\hline An increase in resistance to change & 27 & 2 & 25 & 48 & 18 & 30 & 55 \\
\hline An increase in wage costs & 44 & 3 & 41 & 28 & 20 & 8 & 49 \\
\hline $\begin{array}{l}\text { A better transmission of } \\
\text { professional knowhow }\end{array}$ & 29 & 1 & 28 & 42 & 22 & 20 & 48 \\
\hline $\begin{array}{l}\text { Little enthusiasm for new } \\
\text { technology }\end{array}$ & 22 & 3 & 19 & 48 & 21 & 27 & 45 \\
\hline A more experienced workforce & 37 & 3 & 34 & 27 & 28 & 0 & 34 \\
\hline Career prospects for younger & & & & & & & \\
\hline workers blocked & 21 & 11 & 10 & 35 & 28 & 8 & 18 \\
\hline Greater team complementarity & 14 & 3 & 11 & 41 & 36 & 6 & 17 \\
\hline Lowered productivity & 12 & 10 & 2 & 30 & 43 & -13 & -11 \\
\hline A modification of work organisation & 10 & 12 & -2 & 19 & 53 & .34 & -37 \\
\hline Bad customer image & 1 & 38 & -38 & 5 & 49 & -44 & -82 \\
\hline
\end{tabular}

Read as follows: To the question 'Would an increase in older workers aged 50 and over bring about the presence of a corporate memory?' $62 \%$ of companies replied 'Yes, certainly', $2 \%$ replied 'No, certainly not', $22 \%$ 'Yes, perhaps' and $9 \%$ 'No, I don't think so'.

Source: Ministry of Labour, DARES.

Employers also tend to be positive as to the transmission of skills between generations and the experience of older workers: more than two-thirds of establishments judged these consequences to be certain or probable. And 29 per cent and 37 per cent of establishments respectively replied that such an increase would certainly ${ }^{4}$ have the effect of allowing a better transmission of professional skills and the existence of a more experienced labour force whereas only 1 per cent and 3 per cent respectively believed the opposite. Only a small majority of establishments believed that an increase in the proportion of ageing workers would result in a better complementarity of teams. Only 14 per cent of them believed this consequence to be certain ${ }^{4}$.

Opinions expressed about the role played by ageing employees in the corporate memory and transmission of professional skills are thus positive in the majority and even largely positive. Likewise for opinions expressed as to the experience of this category of the workforce. However, we should point out that these were the only questions allowing establishments to express favourable feelings about ageing workers and, therefore, we might question the real meaning of these judgements, especially since the negative consequences were also mentioned often in very high proportions. The same applies to wage costs: 44 per cent of employers believed that an increase in wage costs was an absolutely certain result of an ageing workforce, while 28 per cent of them saw it as a probable consequence. This was the most important of the negative consequences mentioned.

4 'certainly' refers back to the answer 'Yes, certainly'. Likewise for the adjective 'certain'. 
Negative opinions about ageing employees do not only take into account financial considerations. A frequently voiced criticism of these employees relates to their supposed failure to adapt to new technologies and more generally to change. Almost three-quarters of the organisations in the French survey looked at the consequences of an increase in their numbers in these terms. However, only 27 per cent and 22 per cent respectively declared that such an increase would definitely lead to an increase in resistance to change and a low rate of acceptance of new technologies. Moreover, only one establishment in ten believed that it would definitely be necessary to modify work organization while only one in two believed it would probably be necessary.

Finally, opinions were very mixed as to the drop in productivity that might result from an ageing workforce, although negative responses were more numerous than positive ones. Twelve per cent of establishments believed that it was absolutely certain that an ageing workforce would result in a drop in productivity compared to 30 per cent who believed it was only possible. But another 10 per cent had a completely opposing view: they replied 'No, certainly not' while 43 per cent did not think that it would lead to a drop in productivity.

Thus age does not seem at first sight to be synonymous with a fall in productivity, although this finding should be looked at more closely in the context of the seniority of the employees, their qualifications and the types of jobs they perform, for example. It is noteworthy (see Table 5) that the greater the estimated proportion of older workers, the more the perception of the consequences of an ageing workforce by the employer is a negative one. Answers given vary according to different industrial sectors. The building industry is the most sensitive to the lowering of productivity, but it is also the sector which insists, along with the manufacturing industry, and far more than the service sector, on the importance of corporate memory, a better transmission of knowledge, and the complementarity of working teams.

\section{Table 5: Possible consequences of an increase in the proportion of workers aged 50 and over (France)}

The figures in the table relate to the reply 'Yes, certainly'.

\begin{tabular}{cccc}
\multicolumn{3}{c}{$\begin{array}{l}\text { Estimate of the present proportion } \\
\text { of workers aged }\end{array}$} & 50+ \\
Low & average & large* & Total \\
60 & 67 & 57 & 62 \\
46 & 39 & 54 & 44 \\
28 & 20 & 40 & 27 \\
21 & 16 & 35 & 22 \\
15 & 18 & 32 & 21 \\
43 & 41 & 25 & 37 \\
8 & 7 & 23 & 12 \\
34 & 33 & 20 & 29 \\
9 & 18 & 10 & 14
\end{tabular}

Presence of a corporate memory

An increase in wage costs

Increased resistance to change

Little enthusiasm for new technology

Career prospects for younger workers blocked

A more experienced workforce

Lowered productivity

Better transmission of professional knowhow

Greater team complementarity

* High amalgamates the two estimates Fairly high and Very high.

Read as follows: $60 \%$ of companies estimating their present proportion of $50+$ workers as «low» reply that a possible increase in thia proportion would "Yes, certainly" bring about a the presence of a corporate memory. $67 \%$ of these estimate the actual proportion of older workers as «average» and $57 \%$ as «high».

Source: Ministry of Labour - DARES - 1992 Survey of ageing at work and options for the exit from active life. 
Making comparisons between the findings of the two surveys based on common questions is problematic due to slight differences in the response scales to these questions in the surveys. However, it is clear that employers in each country foresee different consequences of an ageing workforce. Increased labour costs were rated by employers in the French survey as being the most important negative consequence of an ageing workforce, followed by, in descending order: an increase in resistance to change, little enthusiasm for new technology, lower productivity, a need for modification of how work is organised, and a bad customer image. In Britain increased labour costs were rated as being considerably less important relative to other consequences. Instead the main consequences were thought to be an increase in resistance to change and little enthusiasm for new technology followed by, in order: increased labour costs, having to improve working conditions, a need to reorganise the production programme, failing productivity, and a poor image with customers.

\section{Policies practised or envisaged in response to labour shortages}

In the British survey employers were asked whether or not they had in place various strategies to combat labour shortages, or whether or not they thought such strategies might be introduced in the future (Table 6). Strategies aimed directly at utilising older people more effectively were being operated by few employers and were the least used of all recruitment and retention policies we encountered. Approximately 19 per cent stated that they were seeking to recruit more older people while 8 per cent of employers were encouraging later retirement and 7 per cent had partial retirement schemes in place. The figure for partial retirement mirrors that for an earlier study which found that 7 per cent of a sample of organisations with twenty or more employees were operating phased retirement schemes (Copperman, 1981).

Table 6: Percentages of employers in each industrial sector with (a) particular policies currently in place to combat labour shortages and $(b)$ those organisations who would consider such a policy in the future (Britain)

Use of foreign labour

Move production area to where

there is plenty of labour

Use more female labour

Attract potential employees by offering higher

rates of pay and material advantages

Substitute technology for labour

Improve training programmes to increase

adaptability of existing employees

Encourage later retirement

Seek to recruit more older people

Introduce flexible working hours

Introduce a partial retirement scheme

Introduce a job-share scheme

Source: British survey
INDUSTRIAL SECTOR

Index of Manufacturing Services
Production
and Construction

$\begin{array}{rrrrrr}\mathrm{a} & \mathrm{b} & \mathrm{a} & \mathrm{b} & \mathrm{a} & \mathrm{b} \\ 19 & 45 & 8 & 44 & 25 & 38 \\ & & & & & \\ 8 & 27 & 8 & 31 & 7 & 22 \\ 40 & 46 & 41 & 45 & 55 & 23 \\ & & & & & \\ 36 & 47 & 35 & 49 & 34 & 39 \\ 62 & 25 & 63 & 29 & 40 & 33 \\ & & & & & \\ 77 & 19 & 77 & 21 & 64 & 29 \\ 7 & 48 & 6 & 50 & 8 & 48 \\ 11 & 67 & 10 & 67 & 25 & 57 \\ 22 & 45 & 25 & 47 & 37 & 39 \\ 6 & 44 & 7 & 45 & 7 & 58 \\ 18 & 36 & 21 & 36 & 25 & 45\end{array}$


The most frequently used strategy was that of improving training programmes to make better use of existing employees ( 69 per cent), while attracting more female labour (49 per cent) and substituting technology for labour (48 per cent) were also in common use. Seeking to recruit more older people in the future also came behind using foreign labour ( 23 per cent), attracting recruits by offering higher rates of pay ( 35 per cent), introducing flexible working hours ( 31 per cent) and introducing a job-share scheme ( 23 per cent). Overall these findings indicate that, despite the largely positive attitudes reported above, the employment of more older people, or attempting to retain them by encouraging later retirement or introducing partial retirement schemes are not considered as priorities by British employers. Significant numbers of employers said they would consider the employment of older people as a means of overcoming labour shortages in the future but, equally, many said they would not consider later retirement or partial retirement schemes.

Table 6 shows the proportions of employers in each sector of employment operating different recruitment strategies. Statistical analysis indicated that the service sector in general was more likely to be seeking to recruit more older people, to have greater flexibility in working hours and to be using more female labour. The construction and production sectors were more likely to be improving training programmes to make better use of existing employees and to be substituting technology for labour. There were no other differences between sectors, for example, in the numbers encouraging later and partial retirement.

In France, employers are even less ready than in Britain to retain and recruit older workers, and to encourage later retirement. In other words, retaining older workers is not the favoured solution of organisations faced with a shortage of labour. Very few employers envisage keeping on older workers or recruiting more of them (encouraging later retirement or retraining older employees) with a view to overcoming a shortage of labour. Strategies presently employed consist mostly, and in order of importance, of the development of training programmes to adapt the entire workforce ( 74 per cent), the substitution of capital for labour (i.e. modernising and reducing staff numbers) ( 47 per cent), recourse to female labour ( 31 per cent), and lastly the development of part-time work ( 39 per cent) and of flexible working hours (36 per cent) (Table 7).

Table 7: From the list of measures given by which businesses might combat a labour shortage, indicate which ones your own company is already using or would choose in the future (France)

\begin{tabular}{|c|c|c|c|c|}
\hline & SR & already & $\begin{array}{l}\text { in the } \\
\text { future }\end{array}$ & not \\
\hline Recourse to foreign labour & 17 & 14 & 6 & 64 \\
\hline Relocation & 17 & 5 & 4 & 75 \\
\hline Employ more female labour & 18 & 31 & 10 & 41 \\
\hline Attract workers from other companies & 19 & 17 & 18 & 46 \\
\hline Modernise equipment and reduce workforce & 14 & 47 & 26 & 14 \\
\hline Develop training programme & 10 & 74 & 17 & 1 \\
\hline Progressive retirement & 17 & 19 & 35 & 29 \\
\hline Later retirement & 20 & 0 & 12 & 68 \\
\hline Retraining of older workers & 19 & 10 & 24 & 48 \\
\hline Recruit older workers & 21 & 3 & 9 & 68 \\
\hline Introduce flexible working hours & 17 & 36 & 24 & 23 \\
\hline Develop part-time working & 16 & 39 & 22 & 24 \\
\hline
\end{tabular}

Source: MTEFP-DARES, Specific survey of companies 1992. 
With regard to the future, the declared strategies of employers assume roughly the same order of importance. However, recourse to female labour and the improvement of training programmes (already widely used) are envisaged more rarely. Conversely, the use of partial or progressive retirement comes in first position ( 35 per cent), immediately followed by the substitution of capital for labour, introduction of flexible hours and the development of part-time work, which remain in high. It seems that in circumstances of labour shortages, partial retirement may develop strongly. We would note that retraining older workers is the only option frequently envisaged for the future with regard to the retention of older salaried workers. A policy of relocating employment is rarely adopted either as a future option or at present. Similarly, the use of foreign labour is rarely envisaged for the future.

Certain options appear to be associated with the size of the establishment. Thus training and skill development seems already to be in place in the case of large and middlesized establishments, whilst for smaller ones it will assume greater importance in the future rather than the present. The same is true for the substitution of capital for labour.

The recruitment or the retention of older workers is a little-used strategy, whatever the size of the organisation concerned and in whichever sector it may be located. Some differences do appear according to the sector of activity, however. The substitution of capital for labour is obviously more practised and envisaged in industry than in building and public works or in the tertiary sector. Flexible working hours and part-time work are strategies more rarely envisaged in the construction industry than in other sectors. Finally, progressive retirement is a policy even more often seen as the choice for the future in building and public work establishments than by those in other sectors. This observation is no doubt linked to the level of experience of older workers in this sector.

Thus employers appear reluctant, even in the case of a shortage of labour, to preserve and retain their older workers, and even more reluctant to take on more. Only progressive retirement, which enables the maintenance of older workers in part-time employment, is quite often envisaged as a future strategy. Training policies appear in the eyes of management to be a centrally important method of managing human resources for the present and the future, whereas the use of worktime policies (flexible working hours and part-time work) will assume a more important place in years to come. A more worrying trend is the importance granted by employers to the strategy of substituting capital for labour, which is already frequently used by larger organisations and which seems to figure on the future agenda of many small and middle-sized firms.

Comparing the results of the British and French surveys shows some similarities but several major differences. In both Britain and France, increased opportunities for training and re-training appear to be a central part of policies of human resource management. Similarly, in both countries a significant number of employers are seeking to modernise equipment and reduce the size of their workforces. But in both Britain and France it seems that older workers are not being considered as potential solutions to labour shortages. However, while few employers in either survey had introduced policies aimed at encouraging the recruitment or later retirement of older workers, British employers appeared to be more willing to countenance the use of such policies in the future than their French counterparts. On the other hand, French employers were more likely than British ones to 
have introduced programmes of progressive retirement. In addition, employers in Britain were considerably more likely than their French counterparts to have a policy of deliberately trying to attract potential employees through offering better financial packages than other employers.

\section{Conclusion}

The intentions of employers, as observed by this comparative research, diverge markedly from the orientations of the state with regard to the management of older workers. Thus enforced retirement and the encouragement of early exit remain the top-down solutions envisaged most often by organisations to deal with the perceived problem of the ageing of their workforces. However the British and French governments have over the past few years been trying to stem the flow of early exits and have been encouraging employers to keep on their ageing workers. Now, in the case of a large number of employers, solutions involving internal re-organisation of working practices or reclassification are considered as alternatives which are ill-adapted and hence to be excluded, or which are not yet sufficiently well-formulated. However, some room for compromise between employers and the state may be discerned. It is true that employers still opt for encouragement to early retirement as a second line of defence, just behind enforced retirement, but in spite of everything they do express certain reservations about this policy. Indeed, in the French case, almost one-third of them state that, in their opinion, this solution is ill-adapted to deal with workforce ageing. In the British survey, very few employers wanted retirement arrangements to stay as they are and the largest majority ( 45 per cent) favoured the introduction of a flexible decade of retirement. May we deduce from the expression of this reservation on the part of employers that they would be prepared in the long term to revise their practices in this matter?

The interest shown in progressive retirement for the future, in the event of an onset of labour shortages, encourages such a positive conclusion. Although, with the exception of the service sector in Great Britain, both British and French companies show little interest in solutions aimed at keeping on or recruiting older workers. It is even true that delayed retirement, which may well occur in the long term through the effect of the recent reforms of retirement pensions, is resolutely dismissed by employers as a solution to the problem of labour shortages. On the other hand, employers seem to have a large measure of confidence in overall preventive measures directed at the workforce as a whole, such as the intensification of in-house training and the development of flexible worktime, in spite of the risk of further marginalising a section of the workforce thus entailed.

What about the impact of the role of the state in Britain and France? It is likely that the differences between French and British public policies are partly responsible for the differences in the opinions and attitudes of employers in the two countries. French governments were strongly committed over a long period to the policy of early exit whereas, in Britain, recent Conservative governments have favoured passive labour market policies (the Job Release Scheme was a hangover from the more 'active' era of Labour governments). Thus we can discern a greater flexibility on the part of British employers with regard to policies towards older workers, while their French counterparts are reluctant to introduce alternative approaches to the culture of early exit. 
The recruitment and retraining of older workers, or even of keeping them on in the case of a labour shortage, is wholly foreign to human resource management in large French establishments, and is related to only a very small minority of them. As a result, no doubt of the greater incentives and more generous provisions of French early retirement schemes as opposed to British ones, large French employers have acquired the habit of thinking in terms of staff reductions and of the use of early exit for older workers as a means to that end. This facility, along with the presence of generous social protection schemes, has not been available to the same extent to British employers.

By comparing the behaviour and attitudes of employers in the two countries, we may also observe the influence of the neo-liberal economic orientations which hold sway currently among national policy makers in Britain. The use of foreign labour or the relocation of employment, which is widely shunned in France, is fairly well recognised in Great Britain as a legitimate and effective means of facing up to a shortage of labour. 


\section{APPENDIX}

\section{British Survey of Employers' Attitudes and Policies}

The British research reported here was conducted between 1989 and 1993 and consisted of three stages. First a localised survey of 134 men and women aged 55-64. Secondly a national postal survey of large employers in the private and public sectors and, thirdly, indepth follow-up interviews with 100 selected employers from the national survey. This comparative paper concentrates mainly on the second stage because that survey was replicated partly, on a much larger scale, in France and also forms the basis for comparative surveys in Canada and Hungary.

The aims of the survey were to ascertain the extent to which employers were orientating towards older people, what changes they foresaw in the age profile of their workforce over the next 10 years, any evidence of discrimination towards older people, what factors discouraged employers from recruiting and retaining this group, attitudes towards older workers, the organisation's retirement policy, views on the state retirement age and attitudes towards age discrimination legislation.

Data was collected by means of a postal survey of 500 employers, with 500 or more employees, based on a nationally representative sample covering virtually all industrial sectors. (The sector covering agriculture, forestry and fishing was deliberately excluded from the sample.) The questionnaire consisted of a detailed series of questions about employers' attitudes and policies towards the employment of older people and was distributed in 1991.

Three hundred and four questionnaires were returned, representing a response rate of 61 per cent. This is remarkably high for a postal survey and compared with 38 per cent in the only previous British survey of this sort (Thompson 1991). The majority of respondents were personnel managers although a large number were personnel directors or other senior executives.

\section{French Survey of Employers' Attitudes and Policies}

The Ministry of Labour's survey concerns all establishments employing 10 or more people. The field covered is that of industry (excluding production and distribution of energy), construction and public works, the tertiary retail sector (shops, transportation and telecommunications, retail services, banks, insurance, leasing services) and non-retail services (excluding the diplomatic service). Farming, forestry and fishing are therefore not included in the scope of the survey. The sample was graded in terms of activity and size and approximately 9000 questionnaires were sent by post to the establishments in 1992 . They were not addressed to a specific person, although the respondent was requested to describe his or her function within the establishment.

A little over 1500 questionnaires were sent to large establishments (those with 500 or more employees) i.e. almost 90 per cent of the total sample. After two follow-ups the rate of response was 25 per cent. This relatively low response rate might be explained by the complexity of the quesionnaire and the decision to only process those questionnaires that could be matched with the Ministry of Labour's surveys into workforce movements, which 
gave the characteristics of all movements taking place in 1991 within establishments. The response rate was relatively similar for each sector of activity.

The sample of establishments employing 500 people or more (for the purpose of matching with the British sample) amounted in the end to 358 , or almost one quarter of the total sample. Given the rather small size of this number compared to our original anticipations it will not always be possible to carry out sufficiently detailed analyses, especially for activity sectors that are too disparate.

Finally, it is important to note that large establishments represented less than 1 per cent of all those registered in France with UNEDIC on 31.12.1990 and almost 13 per cent of employees (excluding temporary workers) in the field of the survey mentioned above. However, large establishments often have a large number of older employees or those with high seniority. They also have more comprehensive means for managing the workforce (training, internal promotion regrading possibilities). Finally, they are the main users of the age measurement categories defined by the public authorities. This is why a special study of their actions and opinions regarding ageing workers is important. It will later be complemented by a study of smaller establishments for purposes of comparison. 


\section{REFERENCES}

CASEY, B. and G. BRUCHE. 1983. Work or Retirement? Aldershot, Gower.

CASEY, B. and LACZKO, F. 1989. «Early Retired or Long-term Unemployed», Work, Employment and Society, vol.3, No.4, pp.509-26.

COPPERMAN, L. F. 1991. 'Employer Policies and the Older Worker', Research in Corporate Social Performance and Policy, vol. 3, pp.175-201.

DRURY, E. (ed.). 1993. Age Discrimination Against Older Workers in the European Community, London, Eurolink Age.

GUILLEMARD, A.M. 1986 Le Déclin du Social, PUF.

GUILLEMARD, A.M. 1991 «France: Massive exit through unemployment compensation» in Time for Retirement, pp. 127-180.

GUILLEMARD, A.M. 1993 «Travailleurs vieillissants et marché du travail en Europe», Travail et Emploi, No. 57, pp. 60-79.

ITZIN, C. and PHILlIPSON, C. 1993 Age Barriers at Work: Maximising the Potential of Older People, Solihull, Metropolitan Authorities Recruitment Agency.

JONES, A. and L. LONGSTONE. 1990. A Survey of Restrictions on Jobcentre Vacancies. Research and Evaluation Branch Report No. 44, Employment Service.

KOHLI, M., REIN, M., A.M. GUILLEMARD, and H. van GUNSTEREN, H. (eds). 1991. Time for Retirement, Cambridge, Cambridge University Press.

LACZCO, F., A. DALE, S. ARBER and N. GILBERT 1988 «Early Retirement in a Period of High Unemployment», Journal of Social Policy, vol.17, No.2, pp.313-34.

LACZKO, F. and A. WALKER. 1985. «Excluding Older Workers from the Labour Market: Early Retirement Policies in Britain, France and Sweden» in C. Jones and M. Brenton (eds) The Year Book of Social Policy in Britain 1984-85, London, Routledge.

McEWAN, E. (ed.). 1990 Age: The Unrecognised Discrmination, London, ACE Books.

McGOLDRICK, A. E., and J. ARROWSMITH. 1992. «Age Discrimination in Recruitment: An Analysis of Age Bias in Advertisements», Paper Presented at the Conference: «The Employment of Older Workers in the 1990s», Sheffield University, April.

METCALF, H. and M. THOMPSON. 1990. Older Workers: Employers' Attitudes and Practices. IMS Report No. 194, Institute of Manpower Studies.

MUKHERJEE, S. 1973. Through No Fault of Their Own, London, PEP.

NAYLOR, P. 1987. «In Praise of Older Workers». Personnel Management 19(11):44-48.

NEDO. 1989. Defusing the Demographic Time Bomb, London, NEDO.

PHILLIPSON, C. 1983. Capitalism and the Construction of Old Age, London, Macmillan.

SALAIS, R. and STORPER, M. 1993 Les Mondes de Production Ed. Ecole des Hautes Etudes en sciences sociales - Paris.

SCHULLER, T. and WALKER, A. 1990. The Time of Our Life, London, IPPR.

STRAUSS, A. 1988. «A Social World Perspective» in N. Denzia (ed) Symbolic Interaction, vol.1, Greenwich CT: SAI Press, pp.119-128.

TAYLOR, P. and A. WALKER. 1993. «Employers and Older Workers», Employment Gazette, August, pp.371-78. 
THOMPSON, M. 1991. Last in the Queue? IMS Report No. 209, Institute of Manpower Studies.

TILLSLEY, C. 1990. «The Impact of Age on Employment.» University of Warwick.

TRINDER, C. 1990. Employment after 55. National Institute for Economic and Social Research Discussion Paper no. 166.

WALKER, A. 1980. «The Social Creation of Poverty and Dependency in Old Age», Journal of Social Policy, vol.9, No.1, pp.49-75.

WALKER, A. 1982. «The Social Consequences of Early Retirement», The Political Quarterly, vol.53, No.1, pp.61-72.

WALKER, A. 1985 . «Early Retirement: Release or Refuge from the Labour Market?» The Quarterly Journal of Social Affairs 1(3):211-229.

WALKER, A. and TAYLOR, P. 1993. «Ageism vs Productive Ageing: The Challenge of Age Discrimination in the Labour Market.» In Achieving a Productive Ageing Society edited by S. Bass, F. Caro, and Y. Chen. Westport, Greenwood.

WALKER, A., GUILLEMARD, A.M. and ALBER, J. 1993. Older People in Europe - Social and Economic Policies, Brussels, CEC.

WARR, P. and PENNINGTON, J. (1993) 'Views About Age Discrimination and Older Workers' in P. Taylor, et al, pp.75-105. 